\title{
Behavioural analysis in active smoking adolescents to prevent tobacco in a health community
}

\begin{abstract}
Background: analysis of the behavioural in active smoking adolescents to prevent tobacco in a health community from actions doctors is one of the lines of the work team in the consultation of Ceasing Tobacco. Objective: to analyze the behavioural of active smoking adolescents to prevent tobacco in a health community. The investigation embraced one period from September from 2017 to March 2018.
\end{abstract}

Methods: A descriptive study of traverse court was used. Registered to 41 students for sampling intentional no probabilistic, of a universe of 80 adolescent students. It was used empiric methods; interviews structured, questionnaire of Fragrestrom and Test of Richmond.

Results: The masculine sex prevailed, where $51,2 \%$ of the active smoking adolescents was understood between the 13 and 15 years of age, $78 \%$ of these they began to smoke between the 12 and 15 years, of why the most frequent reasons began to smoke it was the relaxation and the pressure group given by a code of companionship.

Conclusion: It was represented that $61 \%$ of the adolescents in study smokes with more frequency in the parties being the road of acquisition more common of the cigarettes in the stores of the state and for traveling sales persons.

Keywords: adolescence, habit of smoking, model function, tobacco, health community, behavior, smoking adolescents, cigarettes, boy's transformation, sampling, own identity, psychological identity, human
Volume 2 Issue 4 - 2018

\author{
Jesús Cuéllar Álvarez \\ Department of Ceasing Tobacco, University Central Marta \\ Abreu de las Villas, Cuba
}

Correspondence: Jesús Cuéllar Álvarez, Department of Ceasing Tobacco, Clinical Psychologist, University Central Marta Abreu de las Villas, Policlinic “José Ramón León Acosta, Cuba, Tel +53 54785830, Email jesusca@infomed.sld.cu

Received: May 08, 2018 | Published: July 30, 2018

\section{Introduction}

The adolescence is essentially a time of changes in which happens the process of the boy's transformation in adult, has characteristic peculiar, and it is also a stage, of discovery of the own identity (psychological identity, sexual identity) as well as of the individual autonomy. The adolescence like period of the human development has been object of the social scientists' attention and of international instances who have tried to define its limits, as well as the characteristics that define this stage. The space of the adolescents has vital importance in the formative process of the personality, propitiating that the same ones can self-teach with a clearer vision of the harmful effects that causes the tobacco and to prevent its consequences with the help of the professionals of the health but with a model function. For model function understands each other those attitudes that impact of positive form or negative on the behaviors of the population's health. The tobacco, is defined as a dysfunction caused by a substance able to produce dependence, the nicotine. It is considered a true drug diffused in the entire world. It reaches a world prevalence of $47 \%$ in the masculine population of adults, in front of $12 \%$ in the woman, and in the last years a more precocious beginning of the habit is observed, particularly in the beginning of the adolescence. ${ }^{1}$ The habit of smoking could be immerse in the integral style of people's life, expert this as the group of individual decisions that affect the health and envelope which you could exercise certain control degree that also has an effect on the health and the behavior of those who cohabit. ${ }^{2}$ The phenomenon that exists around this real problem, conditioned the position of the following scientific problem in the present investigation: How to help prevent tobacco in adolescents in a health community? General objective: To analyze the behavioural of active smoking adolescents to prevent tobacco in a health community.

\section{Methods}

The adolescence was carried out a descriptive study, traverse with adolescents belonging to the policlinic "José Ramón León Acosta" of the municipality Santa Clara, Cuba in the understood period of September 2017 to March 2018, with the objective of analyze the behavioural of active smoking adolescents to prevent tobacco in a health community. It was study object a universe constituted by 41 adolescents and in those that was identified risks related with the tobacco, to those which previously were requested informed consent. Methods of the theoretical level: Analytic synthetic: It facilitated the interpretation of the texts and to establish the corresponding generalizations. Inductive-deductive: facilitated to go of the peculiar to the general thing in each one of the analyses carried out in the theoretical study. Generalization: It allowed the establishment of the regularities that showed in the carried out study.

\section{Empiric level}

Individual clinical histories: It facilitated to offer information on diverse personal aspects of health in the adolescents.

Interviews structured: It contributed to identify the consumption beginning of the consumption of cigarettes in the adolescents.

The questionnaire of Fragrestrom: It was applied with the objective of obtaining information about quantity of cigarettes consumed to determine the degree of dependence nicotinic in adolescents.

Test of Richmond: It was applied with the objective of obtaining information about the methods of obtaining of the cigarettes to determine the internal motivation for the abandonment of smoking in the adolescents. The selection was based on the following approaches: 


\section{Inclusion approaches:}

I. All the adolescents with risks of the area of health that possess favorable psychic conditions to respond the questions.

II. That they resided in the area of chosen health.

\section{Exclusion approaches:}

III. Adolescents that emigrate of their residence place during the study.

\section{Exit approaches:}

IV. Adolescents that abandon the investigation voluntarily.

It was used the following variables starting from the obtained data: age and beginning sex in the tobacco, beginning reasons in the tobacco, quantity of cigarettes consumed by day and way of obtaining of the cigarette. Authorization was requested the adolescents, belonging to the educational policlinic "José Ramón León Acosta" for the realization of the study. To these they were explained the importance of the investigation. The data were used by the specialists of the health and with investigative ends, fulfilling the principle of the confidentiality of the data.

\section{Collection of the information}

To begin the development of the investigation was carried out a bibliographical revision of the topic making a meticulous analysis of the most excellent aspects in the Cuban means as at international level. It was used as technical, the documental revision that included individual clinical histories and it was applied a questionnaire of Fragrestrom and the Test of Richmond detailed previously.

\section{Statistical analysis}

The information was stored in a file of data in SPSS version 21.0 and it is presented in statistical charts; for the description it was calculated the arithmetic stocking, standard deviation, absolute frequencies and percent's. In the analysis it was used non parametric tests as Squared Chi for adjustment kindness and independence of factors. One worked with significance levels to $5 \%$.

\section{Results}

As you it could appreciate in the Table 1 referred to age and beginning sex in the tobacco, the adolescents that begin to smoke in early ages prevailed (12-15 years) represented by 32 of them for $78 \%$, behaving in a very similar way as for the sex, where it was found that in the sex female 8 adolescents for $66,7 \%$ and in the male sex 24 for $82,8 \%$. a difference Exists as for the age average of beginning of the tobacco with regard to the sex, where he/she registered that in the feminine sex it is of 15,2 years and in the 13,8 year-old male sex, for what we can reach the conclusion that the sex male begin to smoke in earlier ages that the female sex. The age average to the beginning of the addiction is significantly smaller in the adolescents of the female sex according to results of the test OR of Mann Whitney with $\mathrm{p}=0,0048$ value. The Table 2 refer to the reasons of beginning of the tobacco according to the sex, where it was appreciated that the most common reason for which the adolescents begin to smoke is to relax, 40 of the 41 adolescents responded this way in study for 97,6 $\%$, it continues him the presence of smoking parents in the home with 31 adolescents for $75,6 \%$ and in third place to feel adult with 29 for $70,7 \%$. it is necessary to highlight that the adolescents with friends that smoke presented a high probability of beginning to smoke, and this way it was reflected in the work, where 28 of the adolescents admitted that they began to smoke because their friends made it, for $68,3 \%$. When analyzing the proportion of adolescents in each sex for each one of the reasons, differences are not evidenced statistically significant according to results of the test Squared Chi with $\mathrm{p}>0,05$ values in each one of the analyses.

Table I Adolescents according to age and beginning sex in the tobacco

\begin{tabular}{|c|c|c|c|c|c|c|}
\hline $\begin{array}{l}\text { Age beginning } \\
\text { in the tobacco }\end{array}$ & $\begin{array}{l}\text { Sex } \\
\text { Female }\end{array}$ & & Male & & Total & \\
\hline & No. & $\%$ & No. & $\%$ & No. & $\%$ \\
\hline I5-Dec & 8 & 66,7 & 24 & 82,8 & 32 & 78,0 \\
\hline $16-18$ & 4 & 33,3 & 5 & 17,2 & 9 & 22,0 \\
\hline Total & 12 & 100 & 29 & 100 & 41 & 100,0 \\
\hline Media $\pm \mathrm{DE}$ & $\begin{array}{l}15,2 \pm \\
1,8\end{array}$ & & $\begin{array}{l}13,8 \pm \\
1,6\end{array}$ & & $\mid 4,2 \pm 1,7$ & \\
\hline
\end{tabular}

Source: Own elaboration.

Table 2 Adolescents according to sex and beginning reason in the tobacco

\begin{tabular}{lllllll}
\hline $\begin{array}{l}\text { Beginning } \\
\text { reasons in the } \\
\text { tobacco }\end{array}$ & Sex & & & & & \\
& Female & & Male & & Total & \\
\hline & No. & $\%$ & No. & $\%$ & No. & $\%$ \\
To feel adult & 8 & 66,7 & 21 & 72,4 & 29 & 70,7 \\
Curiosity & 5 & 41,7 & 14 & 48,3 & 19 & 46,3 \\
Parents that smoke & 9 & 75,0 & 22 & 75,9 & 31 & 75,6 \\
Friends that smoke & 8 & 66,7 & 20 & 69,0 & 28 & 68,3 \\
$\begin{array}{l}\text { To get the } \\
\text { attention }\end{array}$ & 0 & 0 & 3 & 10,3 & 3 & 7,3 \\
Relax & 11 & 91,7 & 29 & 100 & 40 & 97,6 \\
Total & 12 & & 29 & & 41 & \\
\hline
\end{tabular}

Source: Own elaboration.

In the Table 3 were appreciated that they prevail the adolescents that smoke from 11 to 20 cigarettes a day representing for 16 for $39 \%$ of the sample, followed by those that smoke from 6 to 10 cigarettes a day with a total of 10 for $24,4 \%$, although those that smoke more than 20 cigarettes in the day are constituted by 9 equivalent to $22 \%$ where clears up that one speaks of adolescents, which don't have the one per enough capital to satiate their bad habit and for ended it depends on the money that give him their relatives. In connection with the sex it was appreciated that with more frequency the famines consumes from 2 to 5 and of 6 to 10 daily cigarettes, and that both groups represented by 4 adolescents for $33,3 \%$ each one, the masculine sex had a tendency to smoke more, being the group of those that consume from 11 to 20 cigarettes a day the more represented with a total of 14 for $48,3 \%$, followed by those that smoke more than 20 cigarettes in the day with 7 for $24,1 \%$. A relationship is evidenced statistically significant among the quantity of cigarettes consumed daily and the sex according to OR of Mann Whitney with $p=0,049$ value.

In the Table 4 reference is made to the way of obtaining of the cigarette with relationship to the quantity of cigarettes smoked 
in the day, and observes that the main one via for the obtaining of the cigarettes for the adolescents in study is by means of stores and traveling salespersons and this way it is constituted by 25 adolescents for $61 \%$, followed by adult's mediation in which am represented by 10 adolescents for $24,4 \%$, being that of smaller number the adolescents that request cigarettes to its friends for a discreet $14,6 \%$, is necessary to clarify that although the study picks up 7 adolescents with 18 years of age, inside this group they would be 18 that it has not still reached most of age and they obtain even this way the cigarettes by means of state or particular establishments, leaving in evidence the lack of conscience and the salespersons' control. As for the quantity of cigarettes smoked a day it is verified that the most common reason inside the group that smoke is from 2 to 5 cigarettes and they ask its friends, while those that smoke from now on of 6 cigarettes are found that they buy it in stores or to particular salespersons it constitutes the main obtaining way.

Table 3 Adolescents according to sex and quantity of cigarettes consumed per day

\begin{tabular}{lllllll}
\hline $\begin{array}{l}\text { Quantity of } \\
\text { cigarettes }\end{array}$ & Sex & & & & \\
& Female & & Male & \multicolumn{3}{c}{ Total } \\
\hline & No. & $\%$ & No. & $\%$ & No. & $\%$ \\
\hline 5-Feb & 4 & 33,3 & 2 & 6,9 & 6 & 14,6 \\
I0-Jun & 4 & 33,3 & 6 & 20,7 & 10 & 24,4 \\
20-Nov & 2 & 16,7 & 14 & 48,3 & 16 & 39,0 \\
More de 20 & 2 & 16,7 & 7 & 24,1 & 9 & 22,0 \\
Total & 12 & 100 & 29 & 100 & 41 & 100 \\
\hline
\end{tabular}

Source: Own elaboration.

\section{Discussion}

The results of this investigation belonged together since with the world and national tendency every time it increases more the addiction in early ages. It coincides with a study carried out according to the authors $^{3}$ and with other investigations ${ }^{4}$ on the tobacco in adolescents in a community in Spain, where it was reported that the half age of beginning in this habit, is located in the 13 years of age. A study in this respect having offered by another investigator ${ }^{5}$ they outline that the early beginning of the habit of smoking brings future problems of health and it is the entrance door for the consumption of alcohol or other drugs. Due to the early age in that this addiction appears, was carried out this investigation where was appreciated that the committed ages in the study are from 12 to 15 years being predominant the masculine sex, coinciding with ${ }^{6,7}$ that argue that the biggest prevalence in the tobacco is among the adolescents of the masculine sex, standing out the enormous risk that have of smoking the adolescents whose family makes it and the fateful consequences that brings the habit of smoking for its future life. In spite of the present behavior patterns in these adolescents, and the permissive of the habit for some parents and tutors, the way of obtaining of the cigarettes is through friends or contemporary, followed by traveling salespersons. This coincides with that found by other authors, ${ }^{8}$ although it is important to point out that in the study, a group of them obtains it in the schools and the practice of its habit is recurrent, that which is possible for the lack of professors' demand that facilitate the cigarette to the student in many of the cases. On the other hand, other studies for they reflect the place of the smoking adolescents' more frequent consumption $(50,9$ $\%$ ) between friends' house and parties, and in $40,4 \%$ in their houses. According to authors like ${ }^{10}$ they outline that it is known the influence that has the example of the parents to adopt attitudes, by what becomes precise to surround the adolescents of positive examples that redound in the prevention of the tobacco, in order to reinforce the attitudes that go against the adoption of the habit of smoking, and where the family plays a fundamental list, behaving as another factor of risk for the consumption of the tobacco in these precocious ages of the life. In connection with the accessibility to the consumption of cigarettes stood out that in spite of the prohibition of sale of cigarettes to smaller than age in Cuba, $61 \%$ of the interviewed active smokers acquire the cigarettes through the state stores or for traveling salespersons, without discarding that the road easier of obtaining it is by means.

Table 4 Adolescents according to way of obtaining of the cigarettes and quantity of cigarettes smoked in the day

\begin{tabular}{|c|c|c|c|c|c|c|c|c|c|c|}
\hline \multirow[t]{3}{*}{ Way of obtaining of the cigarettes } & \multicolumn{8}{|c|}{ Quantity of smoked cigarettes } & \multicolumn{2}{|c|}{ Total } \\
\hline & \multicolumn{2}{|c|}{2 to 5} & \multicolumn{2}{|c|}{6 to 10} & \multicolumn{2}{|l|}{ II to 20} & \multicolumn{2}{|c|}{ More of 20} & \multirow[b]{2}{*}{ No } & \multirow[b]{2}{*}{$\%$} \\
\hline & No & $\%$ & No & $\%$ & No & $\%$ & No & $\%$ & & \\
\hline Spread or traveling salesperson & 0 & 0 & 5 & 50 & 11 & 68,7 & 9 & 100 & 25 & 61 \\
\hline Offering money to somebody & $\mathrm{I}$ & 16,7 & 4 & 40 & 5 & 31,3 & 0 & 0 & 10 & 24,4 \\
\hline To request to friends & 5 & 83,3 & I & 10 & 0 & 0 & 0 & 0 & 6 & 14,6 \\
\hline Total & 6 & 100 & 10 & 100 & 16 & 100 & 9 & 100 & 41 & 100 \\
\hline
\end{tabular}

Source: Own elaboration.

\section{Conclusion}

The masculine sex prevailed in the study, where the stadium average of beginning to present addiction to the tobacco is in early ages. The most common reasons for those that begin the addiction to the tobacco are to relax, the presence of infection grope among friends, to feel adult, as well as smoking parents in the home that is equal to $75,6 \%$ of adolescents. The place where more smokes the adolescents it is in parties, public places and $61 \%$ low pressure grope marked by a code of companionship are influenced. The main way for the obtaining of the cigarettes is by means of state stores and traveling salespersons that provide it in an irresponsible way.

\section{Acknowledgements}

None.

\section{Conflict of interest}

The Authors declare no conflict of interest. 


\section{References}

1. Álvarez Valdés N, Gálvez Cabrera E, Díaz Garrido D. Hábito de fumar en la adolescencia al nivel comunitario. Rev Cubana Med Gen Integr. 2011;23(3).

2. Martínez E, y Saldarriaga L. Hábito de fumar y estilo de vida en una población urbana. Rev Fac Nac Salud Pública. 2012;29(2).

3. Córdoba R, Villalbí JR, Salvador T, et al. El proceso para la adopción de una legislación eficaz en la prevención del tabaquismo en España. Rev Esp Salud Pública. 2012;80(4):631-45.

4. Larmusch Y. Adolescencia y drogadicción. Un enfoque de la prevención escolar en Argentina. 2014

5. Righetti J. Factores de riesgo en la niñez y adolescencia (Fundamentos de las recomendaciones FAC '99 en prevención cardiovascular). 2014.

6. Satcher D. Las mujeres y el fumar. Dirección General de Salud de los Estados Unidos. 2014.

7. Montero Ramírez G. Hábito de fumar en adolescentes. Educare 2015;8(3):15-18

8. Verra F, Zabert G, Ferrante D, et al. Consumo de tabaco en estudiantes de educación secundaria de Argentina. Rev Panam Salud Pública. 2012;25(3):227-233

9. Ugarte M. La familia como factores de riesgo, protección y resiliencia en la prevención del abuso de drogas en adolescentes. 2014. p. 1-20.

10. González Henríquez 1, Berger Vila K. Consumo de tabaco en adolescentes: factores de riesgo y factores protectores. 2014;8(2). 